\title{
Pengaruh Belis Dalam Masyarakat Sumba
}

\author{
Christofan Dorry Steven \\ Magister Psikologi Sains, Fakultas Psikologi, Universitas Surabaya \\ dorrysteven29.psi@gmail.com \\ Taufik Akbar Rizqi Yunanto \\ Magister Psikologi Sains, Fakultas Psikologi, Universitas Surabaya \\ taufik_yunanto@staff.ubaya.ac.id
}

\begin{abstract}
Belis is an obligation that must be completed by man when he wants to propose Sumba's woman. Belis was identical by the surrender of the mating assets brought while the proposal processed. Belis consist of mamuli, katana, and a number animals such as horses and buffaloes. Determination of the number of belis that must be prepared by the man to propose depends of negotiating or agreement, the social status, and marriage of the girl's mother. If the handover be accepted, the woman must also prepare and carry a bola ngandi containing woven cloth, muti salak, ivory as a form of reply from the belis that will be given to the man. The values of the Belis and the Bola ngandi must be balanced so don't causing humiliations to both families. Belis can have a psychological impact on the lives of individuals and their families. This impact can be seen in self esteem and self efficacy.
\end{abstract}

keywords: sumba; customary marriage; belis

\begin{abstract}
Abstrak
Belis merupakan suatu kewajiban yang harus dipenuhi oleh pihak laki-laki ketika dirinya ingin meminang seorang perempuan Sumba. Belis identik dengan seserahan berupa harta kawin yang dibawa pada saat proses peminangan tersebut. Adapun yang dimaksudkan dengan belis terdiri atas mamuli, katana, dan sejumlah hewan seperti kuda dan kerbau. Penentuan jumlah belis yang harus dipersiapkan pihak laki-laki untuk meminang tergantung pada negosiasi atau kesepakatan, status sosial dan pernikahan ibu si gadis. Apabila seserahan tersebut diterima, maka pihak perempuan juga harus mempersiapkan dan membawa bola ngandi yang berisi kain tenun, muti salak, gading sebagai bentuk balasan dari belis yang akan diberikan kepada pihak laki-laki. Nilai belis dan bola ngandi dalam pernikahan adat Sumba haruslah seimbang agar tidak menimbulkan penghinaan terhadap keluarga pasangan. Belis dapat menimbulkan dampak secara psikologis bagi kehidupan individu dan keluarganya. Dampak tersebut nampak pada harga diri serta keyakinan diri yang dimiliki.
\end{abstract}

Kata Kunci: sumba; pernikahan adat; belis 


\section{Pendahuluan}

Pulau Sumba merupakan salah satu bagian pulau dari Indonesia yang terletak di provinsi Nusa Tenggara Timur. Dulunya pulau ini terbagi menjadi dua kabupaten yaitu Sumba Timur dan Sumba Barat. Seiring berkembangnya waktu, pulau Sumba mengalami pemekaran menjadi empat kabupaten yaitu: Sumba Timur, Sumba Barat, Sumba Barat Daya dan Sumba Tengah. Pulau Sumba sendiri memiliki beragam tradisi-tradisi dan peninggalan sejarah yang masih dipertahankan hingga kini. Woha (2008) menyebutkan beberapa tradisi yang dilakukan dalam masyarakat Sumba antara lain: upacara perkawinan, upacara penyambutan atau penghormatan, serta upacara kematian dan pemakaman.

Lebih lanjut Agus (2018) menyebutkan salah satu tradisi unik di pulau Sumba adalah belis. Belis merupakan salah satu tradisi yang dilakukan dalam upacara perkawinan masyarakat Sumba. Belis ditandai sebagai suatu bentuk pemberian (seserahan) berupa harta kawin yang diberikan oleh pihak keluarga laki-laki terhadap pihak keluarga perempuan. Belis menjadi suatu kewajiban yang harus dipenuhi seorang laki-laki apabila ia ingin melamar seorang perempuan Sumba menjadi isterinya. Di dalam pernikahan adat Sumba, proses pembelisan menjadi hal yang sangat penting. Hal ini dikarenakan tanpa adanya pelunasan belis, maka sebuah pernikahan tidak dianggap sah dalam hukum adat Sumba (Muthmainnah dan Trisakti, 2010).

Belis dalam tradisi pernikahan adat Sumba sudah dilakukan secara turun temurun oleh masyarakat Sumba. Pemberian belis yang dilakukan oleh pihak keluarga laki-laki terhadap keluarga perempuan di mulai ketika proses peminangan (Woha, 2008). Kleden (2017) menyebutkan bahwa terdapat beberapa tahapan yang harus dilalui dalam proses peminangan atau perkawinan adat Sumba diantaranya: tahap pertama 'ketuk pintu', tahap kedua 'masuk minta', dan tahap ketiga 'pindah rumah'. Pada tahap ketuk pintu, seorang laki-laki akan membawa sepasang hewan (kuda) sebagai bentuk ungkapan isi hatinya kepada seorang perempuan dalam suatu keluarga. Hal tersebut juga dianggap sebagai tanda pengikat bahwa perempuan tersebut telah dilamar (Woha, 2008). Belis akan ditentukan dan disepakati pada tahap masuk minta dan harus dilunasi pada saat 
tahap pindah rumah. Adapun belis yang harus dipersiapkan dan dibawa oleh pihak keluarga laki-laki terdiri dari mamuli, katana, dan sejumlah hewan seperti kuda atau kerbau (Muthmainnab dan Trisakti, 2010). Pemberian belis yang dilakukan semata-mata untuk memperat hubungan keluarga yang sudah terjalin sebelumnya. Koten (2017) mengungkapkan bahwa mamuli memiliki peranan yang sangat penting dalam tradisi penikahan adat Sumba. Hal ini dikarenakan mamuli sebagai belis utama dan sebagai lambang pendamaian antara pihak laki-laki dan perempuan. Belis juga memiliki pengaruh yang sangat besar terhadap hubungan baik antara keluarga laki-laki dan perempuan yang ingin melakukan pernikahan. Belis dianggap sebagai wujud dari penghargaan tertinggi untuk perempuan Sumba.

Belis yang dilakukan dalam masyarakat Sumba tidak hanya berlaku bagi pihak keluarga laki-laki yang ingin meminang seorang perempuan Sumba, melainkan pihak keluarga perempuan juga harus mempersiapkan balasan dari belis tersebut. Pihak perempuan akan membawa bola ngandi sebagai bentuk balasan terhadap pinangan yang diterima. Adapun isi dari bola ngandi tersebut berupa kain (hinggi atau lau), sarung, muti salak, dan gading (Mutmainnah dan Trisakti, 2010). Lebih lanjut Kleden (2017) menyatakan bahwa pada saat proses pindah rumah, maka keluarga pihak perempuan akan mempersiapkan barang bawaan berupa lemari, tempat tidur, kursi, meja dan peralatan makan serta babi. Nilai belis dan bola ngandi yang diberikan harus seimbang dalam adat. Hal ini didasarkan pada konsep saling menghargai antar keluarga (Mutmainnah dan Trisakti, 2010)

Proses pembelisan yang dilakukan tidak terlepas dari kesepakatan antara kedua pihak keluarga laki-laki maupun keluarga perempuan. Kesepakatan yang dilakukan akan berkaitan dengan penentuan jumlah besaran belis sera poses berlangsungnya pernikahan adat. Kesepakatan ini ditentukan berdasarkan negosiasi yang dilakukan oleh juru bicara atau wunang dari kedua keluarga. Negosiasi yang dilakukan dalam menentukan jumlah belis dilihat dari status sosial dan pernikahan ibu si gadis (Muthmainnah dan Trisakti, 2010). Boom (2016) menekankan bahwa penentuan jumlah besaran belis yang harus di berikan pihak 
laki-laki kepada pihak perempuan biasanya tergantung pada status sosial calon pengantin dalam hal ini perempuan. Kondisi ini menjadi hal yang sangat berpengaruh bagi kehidupan keluarga dari masing-masing mempelai. Lebih lanjut Kleden (2017) menyebutkan bahwa penentuan jumlah besaran belis harus memiliki dasar pijakan yang kuat bukan mengada-ada atau asal-asalan, seperti latar belakang keluarga, pendidikan dan jumlah belis dari ibu calon pengantin perempuan.

Berdasarkan uraian di atas, maka tujuan dari studi literatur ini adalah untuk memberikan gambaran mengenai dampak psikologis yang muncul dalam tradisi belis di Pulau Sumba-

\section{Pembahasan}

Belis merupakan tradisi yang ada dalam pernikahan adat masyarakat Sumba. Belis erat kaitannya dengan harta kawin sehingga dalam masyarakat Sumba ini menjadi hal yang penting. Seorang laki-laki yang hendak mempersunting seorang perempuan untuk menjadi istrinya haruslah mempersiapkan belis. Wonga (2017) menyebutkan bahwa belis yang diberikan laki-laki adalah benda-benda yang bersifat maskulin seperti kerbau, kuda, parang, tombak dan perhiasan. Sedangkan balasan belis dari pihak perempuan berupa benda-benda yang dekat dengan perempuan seperti kain tenun dan babi. Pada dasarnya urusan belis bukan semata-mata menjadi urusan laki-laki saja melainkan juga pihak perempuan pun harus memberikan balasan untuk belis tersebut. Pemberian belis dan pemberian balasan belis haruslah seimbang. Pemberian banda wili (belis) berupa emas dan hewan belis harus diimbangi dengan pemberian kamba wei (bola ngandi) berupa kain, sarung, hiasan dan babi (Woha, 2008). Hal ini ingin menunjukkan bahwa belis yang diberikan akan berpengaruh terhadap penghargaan dari keluarga.

Seorang perempuan yang dilepaskan oleh pihak keluarganya tanpa adanya proses belis atau proses adat dianggap merendahkan harga dirinya sendiri serta masyarakat akan menilai rendah harkat dan martabatnya (Woha, 2008). Kondisi tersebut menggambarkan bahwa harga diri seorang perempuan Sumba yang akan 
menikah dapat dilihat dari pelaksanaan proses adat serta pembelisan yang dilakukan. Senada dengan laporan Wonga (2017) yang mengatakan bahwa dalam pernikahan masyarakat di NTT, pemberian belis dianggap sebagai bentuk penghargaan dan penghormatan kepada perempuan yang akan dinikahinya. Hal ini berarti proses pemberian belis bagi seorang perempuan Sumba akan berdampak pada harga diri yang akan melekat padanya. Harga diri merupakan evaluasi diri secara menyeluruh yang dilakukan individu dengan cara membandingkan antara konsep diri ideal (ideal self) dengan konsep diri (real self) sebenarnya (Santrock, dalam Hidayat dan Bashori, 2016). Lebih lanjut Darajat (dalam Hidayat dan Bashori 2016) menyatakan proses pembentukan harga diri seseorang ditentukan oleh perlakuan yang diterima dari lingkungannya. Proses pembelisan yang dilakukan dalam pernikahan adat Sumba akan menentukan tingkat harga diri yang dimiliki oleh individu dan keluarga berdasarkan jumlah besaran belis. Penentuan besaran belis pada masyarakat NTT ditentukan oleh pendidikan dan status sosial (Wonga, 2017). Semakin tinggi status sosial seorang perempuan, maka semakin tinggi pula tuntutan belis yang harus dipersiapkan. Hal ini menunjukkan bahwa status sosial yang dimiliki keluarga pihak perempuan akan menentukan jumlah besaran belis pada pihak laki-laki. Golongan atau status sosial yang dimiliki keluarga perempuan menunjukkan bahwa pihak laki-laki yang ingin meminangnya harus berasal dari status sosial yang sama sehingga tidak berdampak pada rendahnya harga diri yang dimiliki pihak perempuan ketika ia dilamar.

Salah satu faktor yang mempengaruhi harga diri adalah keberhasilan seseorang. Keberhasilan dan kegagalan yang dirasakan seseorang akan berkaitan erat dengan harga dirinya. Seseorang yang sering berhasil cenderung memiliki harga diri yang tinggi demikian pun sebaliknya, seseorang yang sering gagal cenderung akan memiliki harga diri yang rendah (Coopersmith, dalam Candra, Harini dan Sumirta, 2017). Pada saat proses pembelisan, pihak laki-laki dituntut untuk melunasi sejumlah belis yang telah diminta oleh pihak perempuan. Pelunasan belis ini akan menentukan kehidupan pihak laki-laki dalam meminang seorang perempuan. Bagi pihak laki-laki yang dapat membayar lunas belisnya 
maka ia dapat dengan mudah membawa istrinya untuk tinggal bersama keluarga laki-laki. Sedangkan apabila belis tidak dapat dibayar lunas oleh pihak laki-laki maka sang suami tidak dapat membawa isterinya untuk tinggal bersama keluarganya melainkan dirinyalah yang harus ikut dan tinggal bersama keluarga perempuan. Hal ini akan berdampak pada harga diri yang dimiliki pihak laki-laki dimana kedudukannya dalam keluarga perempuan bukan sebagai kepala keluarga yang sah.

Menurut Eoleiochta, Leonai dan Dei (dalam Hidayat dan Bashori, 2016), seseorang yang memiliki pengalaman kurang menguntungkan yang dialami sepanjang hidupnya akan menunjukkan harga diri yang rendah. Seseorang yang memiliki harga diri rendah cenderung memandang dirinya negatif dan lebih fokus pada kelemahan-kelemahan yang dimiliki. Pada tradisi belis dalam masyarakat Sumba, seorang laki-laki Sumba yang tidak dapat memenuhi pelunasan belisnya sesuai dengan kesepakatan yang telah ditentukan akan membuat harga diri lakilaki tersebut menjadi rendah di dalam pihak keluarga perempuan. Laki-laki tersebut dianggap tidak memiliki andil dalam segala bentuk pengambilan keputusan yang ada dalam keluarga termasuk dalam hal pemberian nama marga anaknya kelak. Hal ini menunjukkan bahwa laki-laki yang tidak dapat melunasi belisnya akan merasa tidak berdaya dan cenderung merasa tidak beruntung ketika berada dalam keluarga perempuan dikarenakan tidak memiliki hak penuh atas isteri dan anaknya.

Proses pembelisan dalam masyarakat di Sumba juga berkaitan erat dengan seberapa sanggup seorang laki-laki Sumba melunasi jumlah belis tersebut. Sanggup atau tidaknya pelunasan dalam membayar belis ditentukan oleh sebuah keyakinan dalam diri seorang laki-laki pada saat memutuskan untuk meminang seorang perempuan Sumba menjadi isterinya. Keyakinan dalam diri tersebut disebut sebagai efikasi diri. Efikasi diri berkaitan dengan keyakinan bahwa seseorang memiliki kemampuan dalam melakukan tindakan yang diharapkan (Bandura, dalam Alwisol, 2009). Hal ini berarti bahwa seorang laki-laki Sumba akan melakukan proses membayar belis terhadap pihak keluarga perempuan demi seorang perempuan yang ingin dinikahinya. Semakin tinggi tingkat keyakinan diri 
yang dimiliki laki-laki Sumba, maka akan semakin sanggup dirinya untuk melunasi proses pembelisan tersebut. Sedangkan laki-laki yang memiliki keyakinan diri yang rendah akan menjadi tidak berdaya dan cenderung mundur dari proses peminangan tersebut. Hal ini berarti bahwa proses pelunasan belis akan berdampak pada keyakinan diri laki-laki ketika ia hendak melamar seorang perempuan.

Bandura (dalam Hidayat, 2015) juga yang mengatakan bahwa efikasi diri menjadi dasar bagi motivasi individu, kesejahteraan, dan prestasi pribadi. Hal ini terjadi karena mereka percaya bahwa tindakan yang dilakukan akan mencapai hasil yang diinginkan. Kondisi ini akan menunjukkan bahwa seorang laki-laki Sumba memiliki motivasi dalam dirinya untuk melunasi belis yang telah ditentukan. Hal ini juga diungkapkan Bandura (dalam Feist dan Feist, 2010) yang menyebutkan bahwa manusia yang yakin bahwa dirinya dapat melakukan sesuatu yang mempunyai potensi untuk dapat mengubah kejadian di lingkungannya, akan lebih mungkin untuk bertindak dan lebih mungkin untuk menjadi sukses daripada manusia yang mempunyai efikasi diri yang rendah. Kondisi ini menunjukkan bahwa ketika proses pembelisan tersebut telah dilunasi, maka akan berdampak pada kesejahteraan dari laki-laki itu sendiri. Laki-laki yang memutuskan meminang seorang perempaun Sumba akan menunjukkan keyakinan dirinya untuk melunasi belis demi mencapai kesejahteraan bersama.

Keyakinan diri yang dimiliki individu tidak terlepas dari sumber-sumber yang membentuknya. Menurut Bandura (dalam Feist dan Feist, 2010), sumbersumber dari efikasi diri dapat berasal dari pengalaman menguasai sesuatu, modeling sosial, persuasi sosial, dan kondisi fisik. Pada proses pembelisan dalam masyarakat Sumba, keberhasilan dari saudara atau orangtua saat melakukan pernikahan adat akan menjadi sumber utama bagi seorang laki-laki dalam suatu keluarga untuk meningkatkan keyakinan diri yang dimiliki anak laki-lakinya ketika ingin melamar seorang perempuan Sumba menjadi isterinya. Orangtau yang berhasil dalam melakukan tradisi belis akan menjadi modeling bagi anak laki-laki untuk mengikutinya. Hal tersebut dapat meningkatkan keyakinan diri bagi sang anak. Tidak hanya itu saja, kondisi fisik dan emosi dari laki-laki itu 
seperti keadaan ekonomi atau materi (harta benda) akan mempengaruhi keyakinan diri laki-laki untuk melamar perempuan Sumba. Pengaruh dari orang terdekat, seperti om atau paman, dan sahabat juga akan menjadi sumber untuk memperkuat keyakinan diri bagi laki-laki dalam keluarga untuk melamar perempuan Sumba. Hal ini berarti bahwa ketika seorang laki-laki hendak ingin melamar seorang perempuan Sumba akan menunjukkan efikasi diri yang tinggi berdasarkan sumber-sumber yang ada.

\section{Kesimpulan}

Belis merupakan suatu kewajiban adat yang harus dipenuhi oleh seorang laki-laki Sumba, dimana dalam penentuan jumlah besaran belis harus menitikberatkan pada pendidikan dan status sosial, serta pernikahan ibu si gadis. Proses pembelisan ini tidak hanya melibatkan pihak laki-laki semata, pihak perempuan pun memiliki andil untuk memberikan balasan belis sehingga terjalin hubungan yang harmonis tanpa merasa ada pihak yang direndahkan. Proses pemberian belis akan memberikan dampak bagi kehidupan masyarakat Sumba, dimana dampak tersebut akan berkaitan dengan keberlangsungan hidup individunya seperti harga diri dalam keluarga serta keyakinan diri untuk melunasi belis tersebut.

Selanjutnya, bagi peneliti lain yang ingin mengetahui lebih lanjut terkait dengan pengaruh yang timbul dari proses belis, diharapkan dapat menggali dari sisi yang lain seperti relasi antar keluarga dan identitas sosial.

\section{DAFTAR PUSTAKA}

Agus, F. (2018). 5 Tradisi Ajaib Masyarakat Sumba. CNN Indonesia. Diakses Melalui Https://Www.Cnnindonesia.Com/Gaya-Hidup/20180303194158269-280241/5-Tradisi-Ajaib-Masyarakat-Sumba (Pada Tanggal 31 Oktober 2018).

Alwisol. (2009). Psikologi Kepribadian, Edisi Revisi. Malang: UMM Press.

Boom, Aini. (2016). Belis, Tradisi Mahar Untuk Nikahi Gadis NTT Yang Bikin Pria Habis-Habisan. Diakses Melalui 
Https://Www.Boombastis.Com/Tradisi-Mahar-Belis/99946 (Pada Tanggal 31 Oktober 2018).

Candra, I. W., Harini, I. G. A., \& Sumirta, I. N. (2017). Psikologi; Landasan Keilmuwan Praktek Keperawatan Jiwa. Yogyakarta: Andi.

Feist, J. \& Feist, G. J. (2010). Teori Kepribadian Buku 2, Edisi 7. Jakarta: Salemba Humanika.

Hidayat, D. R. (2015). Teori Dan Aplikasi Psikologi Kepribadian Dalam Konseling. Bogor: Ghalia Indonesia.

Hidayat, K., \& Bashori, K. (2016). Psikologi Sosial. Jakarta: Erlangga.

Muthmainnah, L., \& Trisakti, S. B. (2010). Ruang Privat Individu Dalam Sistem Kawin Mawin Masyarakat Sumba Timur. Jurnal Filsafat, 20 (3).

Kleden, D. (2017). Belis Dan Harga Seorang Perempuan Sumba (Perkawinan Adat Suku Wewewa, Sumba Barat Daya, NTT). Studi Budaya Nusantara, 1 (1).

Koten, T. (2017). Mengenal Suku Sumba Di Nusa Tenggara Timur. Diakses Melalui Http://Www.Netralnews.Com/News/Rsn/Read/115778/ProsesPerkawinan-Suku-Sumba-Barat-Nusa-Tenggara-Timur (Pada Tanggal 31 Novemer 2018).

Woha, U. P. (2008). Sejarah, Musyawarah, Dan Adat Istiadat Sumba Timur. Jakarta: Cipta Sarana Jaya.

Wonga, I. (2017). Mahalnya Mahar Nikah Di NTT, Mulai Dari Gading Hingga Uang Puluhan Juta. Diakses Melalui Http://Kupang.Tribunnews.Com/2017/07/07/Mahalnya-Mahar-Nikah-DiNtt-Mulai-Dari-Gading-Hingga-Uang-Puluhan-Juta?Page=All (Pada Tanggal 20 Novermber). 